\title{
Utilizing of Plant Extract Garlic Oil against Aphis Gossypii and Tetranychus Urticae
}

\author{
Khalid A. Aiad \\ Fruit Acarology Department, Plant Protection Research Institute (PPRI), Agricultural Research Center (ARC), Egypt \\ Corresponding author: dr.khaledaiad@gmail.com
}

\begin{abstract}
The toxicity values of Garlic oil plant extract were estimated at concentrations $0.5,0.75,1$ and $1.5 \mathrm{~cm} /$ liter water for controlling Aphis gossypii Glover, 1877 and two spotted spider mite Tetranychus urticae Koch. The obtained results demonstrated that, the highest mortality percentage were $91.3 \%$ and $96.7 \%$ at concentrate $1.5 \mathrm{~cm} /$ liter water for A. gossypii and T. urticae Respectively, meanwhile, the lowest mortality percentage (43.3 $\%$ and $34.7 \%$ for A. gossypii and T. urticae, respectively) was recorded at concentrate $0.5 \mathrm{~cm} /$ liter water .
\end{abstract}

Keyword: Garlic oil, toxicity, $\mathrm{LC}_{50}, \mathrm{LC}_{90}$, Aphis Gossypii and Tetranychus urticae

\section{Introduction}

Chemical pesticides are generally used to control mite and insect pests. The large scale use of chemicals led to the development of resistance to target pests, and consequently also has a negative effect on natural Enemies and other benefits causing disruption of biodiversity (Akram Saleh Alghamdim, 2018). The growing awareness of the shortcoming of the chemical insecticides has necessitated for the exploration for alternative methods of pest control, which is relatively free from adverse side effects. Among the various alternatives, effective control techniques other than insecticide application against insect pests of agricultural crops are highly demanding (El-Heneidy and Sekamatte, 1996; Cho et al. 1995; Zemityet al 2006; Hyun Sik Roh et al 2011; Mariam et al. 2015; Entesar N. Huron et. al. 2016;).

On the other hand, the natural enemies and plant extracts have no residual or persistent toxicity in the agro- ecosystem. (Halawa, 2017).Two spotted spider mite Tetranychus urticae considered a serious pest on world wide Lee et al.(2003).It causes huge injury including flecking, Discoloration(bronzing) and scorching. Although, Aphis gossypii prefers the plants belong to family Fabaceae (beans, peas and groundnuts), it is highly polyphagous and has been found on many plant species feeding on the young shoots, leaves, flowers and fruits Aiad . K .A.(2013) and Pervin Erdogan et al.(2012).

A.gossypii is a vector of several viruses including broad bean mosaic virus, cucumber mosaic virus and groundnut rosette virus Akram Saleh Alghamdi(2018) and Sharifah Fathiyah Sy Mohamada et al. (2013). The cowpea aphid has a cosmopolitan distribution. Therefore, recent control technology and relevant tactics reduce the either pesticides application and environment pollution which purposed to achieve sustainable management of pests control. This study aims to throw light on utilizing the different concentrations of garlic oil to control of A. gossypii and T. urticae as one of IPM factors

\section{Material and Methods}

A pure culture of A. gossypii and T. urticae were separately propagated on leaves of Phaseolus vulgaris L. Leaf discs of about three-inch in diameter were made and Washed with running water to remove any possible residuals or organisms which may be found on these leaves. The leaf discs were surrounded by tangle foot, which acts as a barrier to prevent mite or insect individuals from escaping and placed on pieces of moisten cotton wool in Petri dishes of $300^{\mathrm{cm}}$ diameter, Twenty leaf discs were used as replicates $50 \mathrm{~A}$. gossypii individual were placed on each discs, while, 30 individual from $T$. urticae were placed on other twenty discs as separate experiment.

Four concentrations of Garlic oil plant extract $(0.5,0.75,1,1.5 \mathrm{~cm} /$ liter of water) were prepared to evaluate the mortality percentage of A. gossypii and movable Stages of T.urticae. Five treatments were conducted under laboratory conditions, .one liter plastic sprinkler used from a distance $20 \mathrm{~cm}$ to get evenly fog droplets on plant surface. The control replicates had water by the same previous methode . Mortality percentage were taken after 48 hours. The LC $^{50}$ were calculated according to Finney (1971).

\section{Result and Discussion}

The impact of Garlic oil toxicity at concentrations $0.5,0.75,1,1.5 \mathrm{~cm} / \mathrm{liter}$ of water on mortality percentage of insect pest $A$. gossypii and mite pest $T$. urticae is depicted in tables 1 and 2, respectively, while the comparison of garlic oil toxicity between the mentioned pests was recorded in table 3 . In general, the results in tables 1 and 2 showed that, no mortality percentages of $T$. urticae and A. gossypii were recorded in the control of all experiments. On the other hand, the obtained data from table(1) and fig(1) denoted to the mortality percentages of $A$. 
gossypii at concentrations $0.5,0.75,0.1$ and 1.5 $\mathrm{cm} /$ liter water which were $43.3,56,82$ and $91 \%$, Respectively, while, $\mathrm{LC}_{50}$; $\mathrm{LC}_{90}$ and slop values were $0.59 \mathrm{mg} / 1,1.24 \mathrm{mg} / \mathrm{l}$ and $3.4 \mathrm{mg} / \mathrm{l}$ Respectively.

Therefore, the data represented in table (2) and fig (2) showed that the likewise, a similar trend was observed concerning $T$. urticae individuals mortality percentages that were significantly increased as the concentrations which recorded at the same concentrations $(0.5,0.75,1,1.5 \mathrm{~cm} / \mathrm{liter}$ of water) were $34.7,48.7,94$ and $96.7 \%$ whereas, the $\mathrm{LC}_{50}, \mathrm{LC}_{90}$ and slop values of movable stage of $\boldsymbol{T}$. urticae were $0.64 \mathrm{mg} / 1,1.13 \mathrm{mg} / \mathrm{l}$ and $5.2 \mathrm{mg} / \mathrm{l}$, Respectively. The results mentioned above in the our study revealed that, the individual mortality percentages of $\boldsymbol{A}$. gossypii and $\boldsymbol{T}$. urticae gradually increased with the increase of garlic oils concentrations. Previous studies which agreed with the present work have indicated how various essential oil efficient against pests on plants. Most of the studies reported great potentials of the essential oils to control pests so, the present results are in accordance with those recorded by Akram Saleh Alghamdi in (2018) evaluated the toxicity of four essential oils moringa (Moringa oleifera), arugula (Eruca sativa), radish (Raphanus sativus), and garlic (Allium sativum) at the concentrations of $1 \%$, $2 \%$, and $4 \%$ on mortality percentage of Macrosiphum rosae and Aphis Fabae and found that the individual mortality percentages increased with the increase of essential oils concentrations tested at the different exposure duration. In addition the same author mentioned that the garlic oil was recorded the highest mortality percentage of $M$. rosae and $A$. fabae after arugula oil at all concentrations
Furthermore, the present results are agreed with the previous results that recorded by Aiad (2013) who evaluated four plant extracts (Aqueous garlic ' Anise oil 'Garlic oil and linen seed oil) at concentrations 1; 1.5 and $3 \mathrm{~cm} /$ liter of water on the two spotted spider mite Tetranychus urticae and found that the mortality Aqueous garlic extract was the most effective $86 \%$ and $96 \%$ at concentrations 1.5 and 2 $\mathrm{cm} /$ liter water, respectively . while, the mortality of Anis oil was $68 \%, 69 \%$ and $90 \%$ at concentrations $1^{\mathrm{cm}} 1.5^{\mathrm{cm}}$ and $2^{\mathrm{cm}} /$ litre of water, respectively. In addition that several authors in previous studies evaluated different plant extracts on the mortality percentage of $\boldsymbol{T}$. urticae such as

Pervin Erdogan et al. (2012) who determined the effficacy of plant extracted from five different plants [Allium sativum L.(Amaryllidaceae), Rhododendron luteum S. (Ericaceae), Helichrysum arenarium $\mathbf{L}$. (Asteraceae), veratrum album L. (Liliaaceae), and Tancetum parthemium $\mathbf{L}$ (Asteraceae)] and found that high moratlity percentage of $\boldsymbol{T}$. urticae was caused by the lowest- concentration of the plant extracts mentiond above. Therefore, th mite pest $\boldsymbol{T}$. urticae was affected by the plant extract camphor (100\%) through the study that carried out by Ghada E. A et. al. (2015)

Conclusion: This investigation indicated the possible use of such essential oils at low concentration against two species of pest tested in vitro. Therefore, future studies are needed to characterize the active compounds in the tested essential oils that have pesticidal properties and possessing complex modes of action before recommend it for IPM program against $A$. gossypii and T. urtcae.

Table 1. Evaluation toxicity of Garlic oil plant extract on A. Gosypii

\begin{tabular}{lcccccccc}
\hline Tested organisms values & \multicolumn{7}{c}{ Concentrations } & \multicolumn{2}{c}{$\begin{array}{c}\mathrm{LC}_{50} \\
\mathrm{mg} / \mathrm{L}\end{array}$} & $\begin{array}{c}\mathrm{LC}_{90} \\
\mathrm{mg} / \mathrm{L}\end{array}$ & slop \\
\hline & 0.5 & 0.75 & 0.1 & 1.5 & & & 3.4 \\
A.gossypii & 43.3 & 56 & 82 & 91.3 & 0.59 & 1.24 & 3. \\
Control & 0 & 0 & 0 & 0 & - & - & - \\
\hline
\end{tabular}




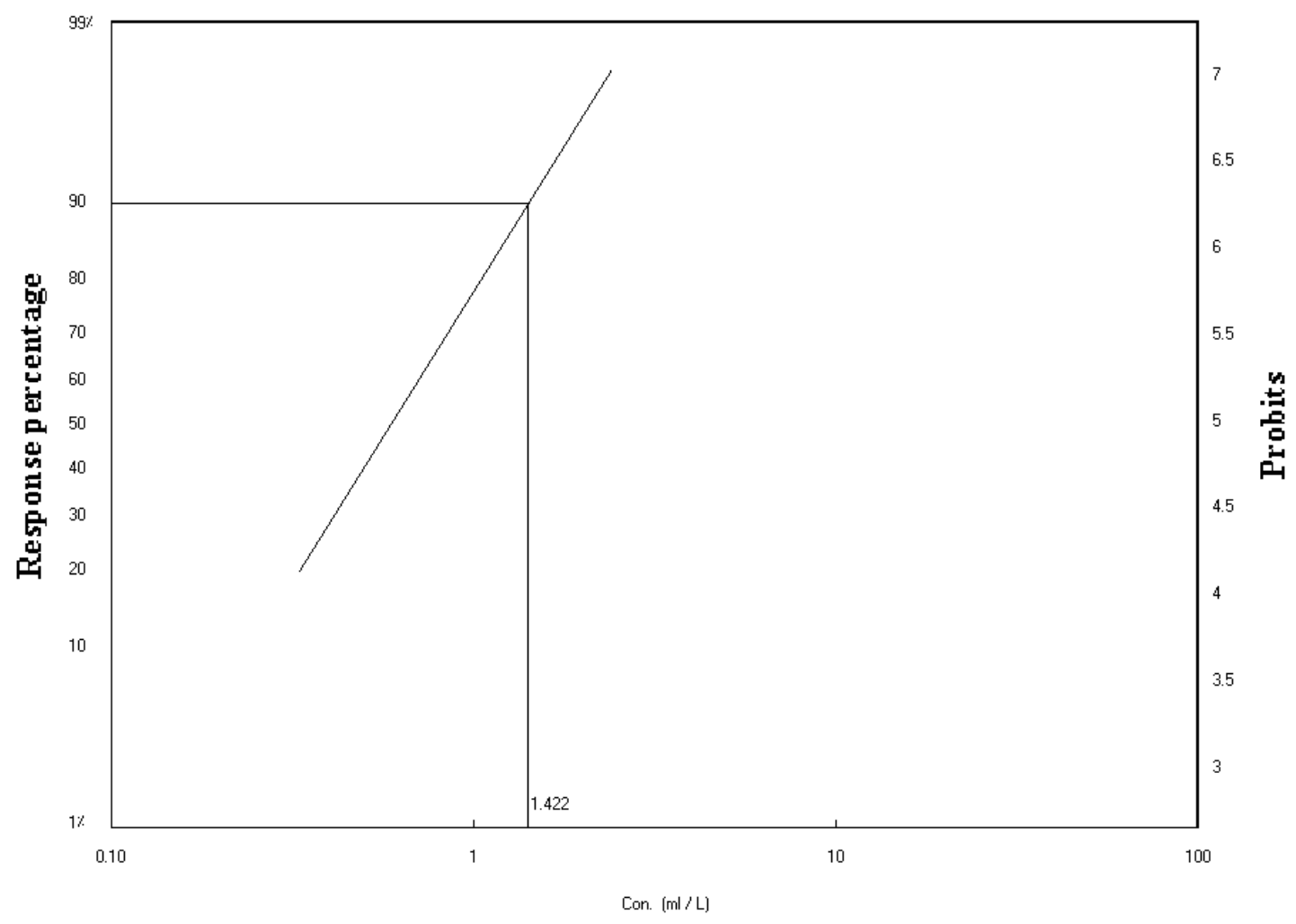

Fig. 1. Toxicity of Garlic oil plant extract against Aphis gossypii.

Table 2. Evaluation toxicity of Garlic oil plant extract on T. urticae

\begin{tabular}{lccccccc}
\hline Tested organisms values & \multicolumn{2}{c}{ Concentrations } & & $\begin{array}{c}\text { LC } \\
\mathrm{mg} / \mathrm{L}\end{array}$ & $\begin{array}{c}\text { LC } \\
\mathrm{mg} / \mathrm{L}\end{array}$ & Slop \\
\hline & 0.5 & 0.75 & 0.1 & 1.5 & & & \\
Movable stage of $T$. urticae & 34.7 & 48.7 & 94 & 96 & 0.64 & 1.13 & 5.2 \\
Control & 0 & 0 & 0 & 0 & - & - & - \\
\hline
\end{tabular}

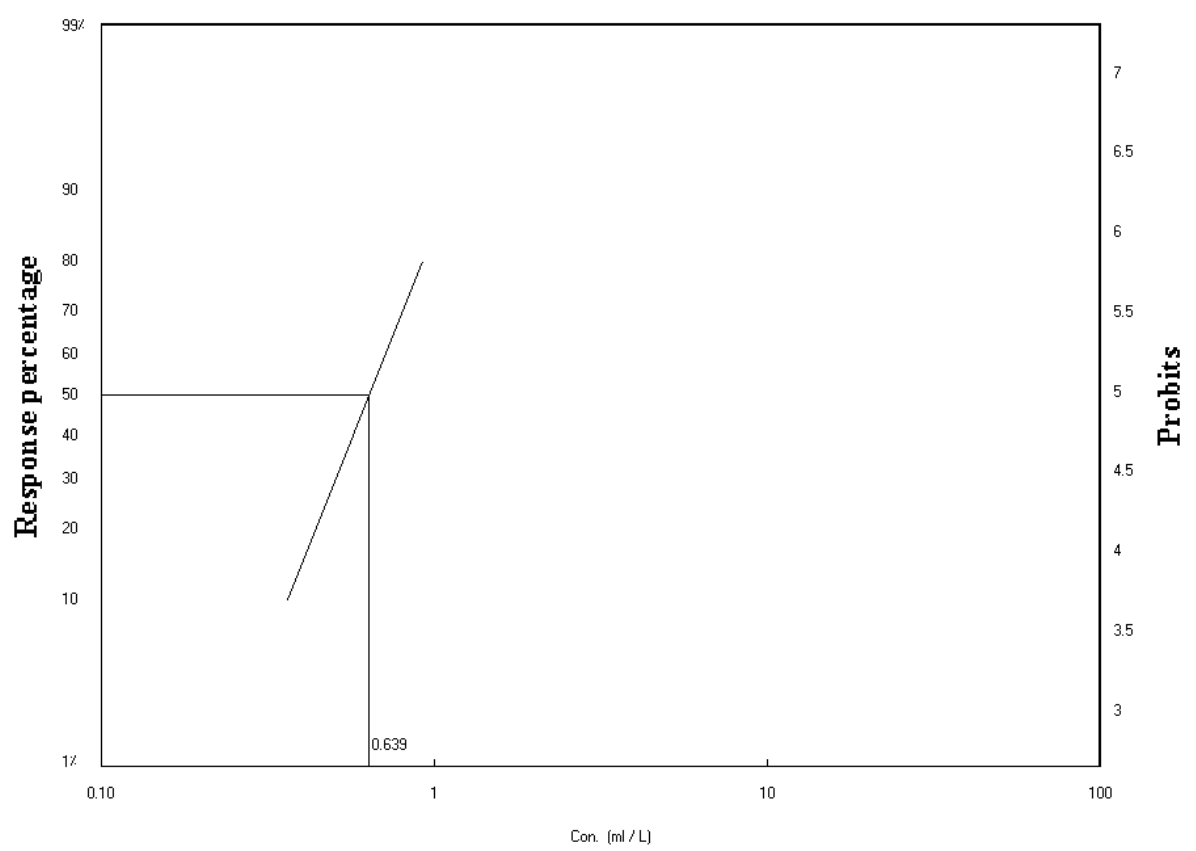

Fig.(2): Toxicity of Garlic oil plant extract against movable stages of Tetranychus urticae 
Table 3. Comparison of Garlic oil toxicity between Aphis gossypii. And T. urticae

\begin{tabular}{|c|c|c|c|c|c|c|c|}
\hline \multirow[t]{2}{*}{ Tested organisms values } & \multicolumn{4}{|c|}{ Concentrations } & \multirow{2}{*}{$\begin{array}{l}\mathrm{LC}_{50} \\
\mathrm{mg} / \mathrm{L}\end{array}$} & \multirow{2}{*}{$\begin{array}{l}\mathrm{LC}_{90} \\
\mathrm{mg} / \mathrm{L}\end{array}$} & \multirow[t]{2}{*}{ slop } \\
\hline & 0.5 & 0.75 & 0.1 & 1.5 & & & \\
\hline A.gossypii & 43.3 & 56 & 82 & 91.3 & 0.59 & 1.24 & 3.4 \\
\hline Movable stage of $T$. urticae & 34.7 & 48.7 & 94 & 96 & 0.64 & 1.13 & 5.2 \\
\hline control & 0 & 0 & 0 & 0 & - & - & - \\
\hline
\end{tabular}

\section{References}

Aiad k. A. 2013. Evaluation the acaricide effects of some plant extracts on two spotted spider mite Tetranychus urticae Koch under laboratory condition (Acari: Tertanychidae) J.PlantProt. and Path., Masoura Unvi., vol.4 (7): 689-692.

Akram Saleh Alghamdi 2018. Insecticidal effect of four plant essential oils against two aphid species under laboratory conditions Journal of Applied Biology \& Biotechnology Vol. 6(2), pp. 27-30

Cho JR, Kim YJ, Ahn YJ, Yoo JK, Lee JO (1995) Monitoring of acaricide resistance in fieldcollected populations of Tetranychus urticae (Acari: Tetranychidae) in korea. Korean J Appl Entomol 34:40-45.

Entesar N. Huroul, Afaf A. Abbas, Neama A. Abd El- Hamid, Maha, S. Nadal and T.R. Amin (2016) Toxicity and acute macromolecular abnormalities induced by some plant extracts against the Cowpea aphid; Aphis craccivora Koch. J. Plant Prot. And Path., Mansoura Univ., Vol.7 (7): 445-449.

Finney, J., (1971) Probit Analysis, $2^{\text {nd }}$ Ed. Cambridge University Press, Cambridge, UK.

Halawa A.M.(2017) Possibility of Utilizing The Predatory Mite, Neoseiulus californicus (Mcgregor) (Acari: Phytoseiidae) For Controlling Two Eriophyoid Fig Mites, Aceria ficus (Cotte) and Rhyncaphytoptus ficifoliae Keifer (Acari: Eriophyoidea) Menoufia J. Plant Prot., Vol. 2 June (2017): 223 - 230.

Hyun SikRoh, Eu Gene Lim, Jinwookim (2011) Acaricidal and oviposition deterring effects of santalol identified in sandalwood oil against twospotted spider mite, Teranychus urticae Koch
(Acaari: Tetranychidae) J Pest Sci (2011) 84:495501.

Ghada E.A. and Amal.E.M (2015) Efficacy of certain compounds of plant extracts of controlling cotton leaf worm, spodoptera littoralis (Boisd). Edgypt. J.Agric. Res., 93 (1) (A).

Lee YS, Song MH, Ahn KS, Lee Ky, Kim JW, Shin Sc, Kim GH (2003) Monitoring of acaricide resistance in two spotted spider mite (Tetranychus urticae) populations from rose green houses in Korea. J Asia- Pac Entomol 5:237-240.

Mariam G.H., Amal E.M. And GhadaE.A.(2015) the toxic effect of basil deravitives, Ocimum basilicum., on two species of tetranychus spp.(Acari: Teranychidae) Egypt. J.Agric. Res., 93 (1) (A).2015.

Pervin Erdogan, Aysegulyildirim, and Betul Sever (2012) Investigations on the Effects of five Different plant extracts on the Two- Spotted Mite Tetranchus urticae Koch (Arachnida: Tetranchidae) A journal of Entomology Volume (2012), Article ID 125284, 5 Pages.

Saad El Zemity, HussienRezk, SaherFarok, Ahmed Zaitoon (2006) Acaricidal activities od some essential oils and their against house dust mite, Dermatophgoide sterongssinus (Acari: pyoglyphide) JZhejiangeUnive SCIENCE B 7(12): 957-962.

Sharifah Fathiyah Sy Mohamada, ShahrilMohamada, Azila Abdul Azizb(2013)The Susceptibility of Aphids, Aphis gossypii Glover to Lauric Acid based Natural Pesticide Procedia Engineering (53 ) 20-28

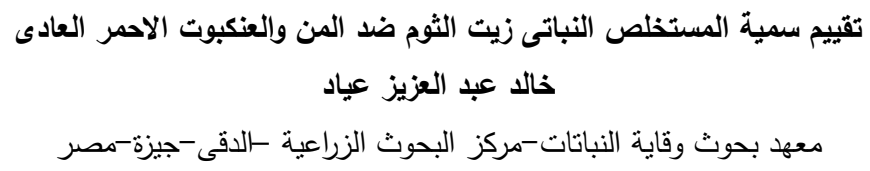

قدرت سمية المستخلص النباتى لزيت الثوم على القطن بتركيزات 0.5 و 0.75 و 1.0 و 1.5 سم/لتز فكانت نسبة الموت 43.3 46 56 ، 52 ، 91.3\% على التوالى وبنفس النركيزات قدرت سمية المستخلص على الأطوار المتحركة من العنكبوت الأحمر ذات البقعتين وكان تأثثر سمية المستخلص النباتى على نسبة موت الأطوار المتحركة هى كالتالى : 34.7 ، 48.7 ، 94 ، 96 \% 